\title{
Histopathological Study and Oxidative Stress, Antioxidants Parameters and Liver Enzymes Activity Determination of Cyperus Methanolic Extract and Glucophage Drug on Albino Male Mice
}

\author{
Ruqaya Mohammed Al-Ezzy ${ }^{1, *}$, Sura Alaa Soud ${ }^{2}$, Zahraa Mohand Sadoon ${ }^{1}$ \\ ${ }^{1}$ Departement of Molecular and Medical Biotechnology, College of Biotechnology, Al-Nahrain University, Baghdad, Iraq \\ ${ }^{2}$ Departement of Microbiology, College of Science, Al-Karkh University of Science, Baghdad, Iraq \\ Email address: \\ ruqaia.alezzy83@yahoo.com (R. M. Al-Ezzy) \\ ${ }^{*}$ Corresponding author
}

\section{To cite this article:}

Ruqaya Mohammed Al-Ezzy, Sura Alaa Soud, Zahraa Mohand Sadoon. Histopathological Study and Oxidative Stress, Antioxidants Parameters and Liver Enzymes Activity Determination of Cyperus Methanolic Extract and Glucophage Drug on Albino Male Mice. American Journal of Bioscience and Bioengineering. Vol. 7, No. 1, 2019, pp. 10-15. doi: 10.11648/j.bio.20190701.12

Received: February 26, 2019; Accepted: April 2, 2019; Published: April 26, 2019

\begin{abstract}
The study aimed to explain the hepatoprotective action of Cyperus rotundus methanolic extract in vitro and in vivo (albino male mice). An interaction between the extract and Glucophage drug were also made to evaluate the in vivo modulating effects of the extract. The hepatoprotective evaluations included assessment of malondialdyde (MDA) and catalase (CAT) activities and liver function enzymes (aspartate aminotransferase; AST and alanine aminotransferase; ALT and alkaline phosphatase; ALP) in blood serum, as well as histopathological estimation of liver tissue, in mice after administration of the drug Glucophage and cyperus rotundus methanolic extract alone or with interaction. The results indicated that the plant extract $(200 \mathrm{mg} / \mathrm{kg})$ decreased MDA activity and increase significantly activity of catalase in comparison to positive and negative controls. Also Cyperus rotundus methanolic increase the level of ALT, AST and ALP. The drug Glucophage was contributed to increased MDA activity and decreased the activity of catalase in comparison to positive and negative controls in addition to increase the activity of ALT, AST and ALP. The interaction between the extract and glucophage increased both MDA and catalase activity in comparison to control group. In addition to increase the liver function enzymes ALT, AST and ALP. The histopathological activity represented that histopathological section in the liver of mouse treated with Cyperus rotundus extraction showed scattered degenerated cells while histopathological section in the liver of mouse treated with Glucophage showed normal architecture with few pyknotic nuclei. Histopathological section in the liver of mouse treated with Cyperus rotundus and Glucophage showed multiple aggregation mononuclear cells around central vein.
\end{abstract}

Keywords: Cyperus rotundus, Glucophage, Catalase Enzyme and Malondialdyde

\section{Introduction}

The important role of Plants guide to development of new drugs [1]. Phytochemicals are the usual compound arise in plants, vegetables and fruits, that effort with nutrients and fibers to act against diseases [2]. In addition to the toxic rudiments such as mercury, arsenic, lead, nickel and cadmium which might be present in some plants had the ability to threaten the consumer health, especially the children and elderly. A useful element such as calcium, magnesium, zinc, manganese and iron are also usually present in plants which improve good health [3]. One of this imperative plant is Cyperus rotundus. Cyperu srotundusis a large genus of about 700 species of sedges, distributed all the way through all continents in both tropical and temperate regions [4]. Phytochemical studies have made known that the major chemical components of Cyperus rotundus are essential oils, flavonoid, terpenoids, and mono sesquiterpenes [5]. The plant contains the following chemical constituents; cyprotene, acopaene, cyperene, aselinene, rotundene, 
valencene, cyperol, gurjunene, trans-calamenene, dcadinene, gcalacorene, cadalene, amuurolene, gmuurolene, cyperotundone, mustakone, isocyperol, acyperone [6] and 4, 11-selinnadien-3-one and 1,8-cineole [7]. The oil of $C$. rotundus was primarily composed of cyperol, $\alpha$-cyperene, rotundine, $\alpha$-cyperone, $\alpha$-copaene, valerenal, myrtenol, $\beta^{-}$ pinene, $\alpha$-pinene and $\alpha$-Selinene, sesquiterpene hydrocarbons (Caryophyllene) [8]. According to the Ayurveda, C. rotundus rhizomes are considered astringent, diaphoretic, diuretic, analgesic, antispasmodic, aromatic, carminative, antitussive, emmenagogue, litholytic, sedative, stimulant, stomachic, vermifuge, tonic and antibacterial [9]. Glucophage is a prescription medication used to treat type 2 Diabetes [10]. Glucophage belongs to a group of drugs called biguanides, which work by helping body respond better to the insulin it makes naturally, decreasing the amount of sugar in liver makes, finally, Glucophage has different benefits including [11]. Glucophage (Metformin) treats and prevents type 2 diabetes, improves Insulin resistance, treats symptoms of polycystic ovary syndrome (PCO) etc...

\section{Methods}

\subsection{The Plant Cyperus Rotundus}

C.rotundus is collected from local market as dried powder material which previously recognized by National Iraqi herbarium.

\subsubsection{Preparation of Plant Extract}

The procedure of [12] was followed to prepare the methanolic extract of C.rotundus. Fifty grams of the plant leaf powder were extracted with $80 \%$ methanol $(250 \mathrm{ml})$ at $65^{\circ} \mathrm{C}$ for 3 hours using the soxhlet gadget. The extract solution was strenuous to dryness under reduced pressure in a rotary evaporator to acquiesce dried crude extract, which was frozen at $-20^{\circ} \mathrm{C}$ until use to prepare the required doses.

\subsubsection{Dose of Plant Extract (C. Rotundus)}

In albino male mice, only one dose of the extract was used $(200 \mathrm{mg} / \mathrm{kg})$ [13].

\subsection{Dose of Drug (Glucophage)}

In albino male mice, only one dose of the drug was used (500 mg/kg).

\subsection{Assessment of Hepatoprotective Effects}

Hepatoprotective effects were assessed in albino male mice after inducing hepatic damage with Glucophage. The parameters of assessment were malondialdehyde and catalase activities in liver tissue homogenate and liver function enzymes in serum, as well a histopathological evaluation of liver tissue to detect any damage.

\subsubsection{Determination of Malondialdehyde (MDA)}

Determination of MDA (which is considered as an index of lipid peroxidation) was based on the reaction of MDA with thiobarbituric acid acid (TBA), which gives a pink colored
TBA-MDA product. The assay was carried out according to a method presented by [14]. An aliquot $(1 \mathrm{ml})$ of liver tissue homogenate supernatantwas transferred to $10 \mathrm{ml}$ test tube, while $1 \mathrm{ml}$ of distilled water was added to a second test tube and marked as blank. To each tube, $1 \mathrm{ml}$ of TCA (17.5\%) was added, followed by adding $1 \mathrm{ml}$ of TBA $(0.6 \%)$. The tubes were vortexed and incubated in a water bath at $100^{\circ} \mathrm{C}$ for 15 minutes, and then cooled immediately to room temperature for 10minutes, followed by an addition of $1 \mathrm{ml}$ of TCA $(70 \%)$ and shaked well and left to stand for 20 minutes at room temperature. Then, the test tubes were centrifuged for 15 minutes at $2000 \mathrm{rpm}$ and the supernatant was separated and transferred to another test tube. Finally the absorbance was read at $534 \mathrm{~nm}$.

\subsubsection{Determination of Catalase (CAT) Activity}

Catalase activity was measured by the method of [15]. Liver homogenate supernatant or standard $(0.1 \mathrm{ml})$ was dispensed into a cuvette containing $1.9 \mathrm{ml}$ of $50 \mathrm{mM}$ phosphate buffer. Then, $1.0 \mathrm{ml}$ of freshly prepared $30 \mathrm{mM}$ hydrogen peroxide was added, and the rate of hydrogen peroxide decomposition was measured spectrophotometrically at $240 \mathrm{~nm}$ and the absorbance was recorded after 10 minutes. The activity was expressed as unit $/ \mathrm{ml}$ protein after estimating protein concentration in the tested sample.

\subsubsection{Assessments of Aspartate Amino-Transferase (AST), Alanine Aminotransferase (ALT) and Alkaline Phosphotase (ALP)}

The enzymes activities of AST, ALT and ALP were determined in the mice serum kit [16]. (Randox Company).

\subsubsection{Histopathological Evaluation of Liver}

The liver was fixed in $10 \%$ formalin for 48 hours, and the procedure of [17] was followed to prepare sections for histopathological examinations. The procedure is outlined as the following: Washing the sample in $70 \%$ ethanol overnight followed by dehydration by of ethanol at different concentrations. Then, the sample placed in paraffin-xylene (1:1) for 30 minutes at $57-58^{\circ} \mathrm{C}$, and then in paraffin alone for 2 hours at $60-70^{\circ} \mathrm{C}$. Then, sample was embedded in pure paraffin wax (melting temperature: $60-70^{\circ} \mathrm{C}$ ) and left to solidified at room temperature. The paraffin block was sectioned (rotary microtome) at a thickness of 5 microns, and then the sections were transferred to a slide covered with Mayer's albumin. The section of tissue was placed in a water bath $\left(35-40^{\circ} \mathrm{C}\right)$ for few seconds. Finally, staining and the slide were cleared with xylene for 10 minute and the slide was mounted with a Canada balsam and covered with a cover slip. Then, the slide was examined microscopically to inspect the histopathological changes.

\subsection{Experimental Design}

Four groups were tested in this stydy (distilled water Control negative), (mice administrated Glucophage drug GroupII), (mice administrated Cyperus rotundus methanolic extract Group III) and for interaction group the mice were 
administered IP with $(0.1 \mathrm{ml})$ of the dose of cyperus rotundus from (1-3) days and drug from (4-6) days and then completed with cyperus rotundus methanoic extract for (7-8) days (Group IV). Then, the mice were scarified at day 9 in order to assess the hepatoprotective activity of both cyperus rotundus and Glucophage.

For the group I, II and III, the tested materials were IP injected, and mice were sacrificed and dissected in day 8 . Before sacrificing the mouse, blood was collected by heart puncture and allowed to clot at room temperature for 15 minutes, and then serum was obtained by centrifugation at $3000 \mathrm{rpm}$ for 10 minutes. The serum was used for the assessment of liver function enzymes (aspartate aminotransferase; AST and alanine aminotransferase; ALT), in addition to alkaline phosphatase (ALP). After blood collection, the mouse was sacrificed and dissected to obtain the liver. One piece of the liver was fixed in $10 \%$ formalin for histopathological examination. A further piece of liver was perfused with cold physiological saline to completely remove all erythrocytes, and cut into small pieces. One gram of these pieces was transferred to a tube of $(1 \mathrm{ml})$ cold $0.1 \mathrm{M}$ phosphate buffer ( $\mathrm{pH}$ 7.4) and homogenized using a homogenizer. After centrifugation (2000 rpm for 10 minutes), the tissue homogenate was scatterbrained, distributed into aliquots and frozen at $-20^{\circ} \mathrm{C}$ for later use in the estimation of malondialdehyde (MDA) and catalase (CAT). This protocol was adopted from [12].

\subsection{Statistical Analysis}

The values of the investigated parameters were given in terms of mean \pm standard deviation (SD), and differences between means were assessed by analysis of variance (ANOVA) followed by least significant difference (LSD) or Duncan test, using the computer programme SPSS version 13.0. The difference was considered significant when the probability value was equal or less than 0.05 . For in vitro parameters, the mean was based on a triplicate assessment of each test, while in in vivo assessments; it was based on four observations (four mice) [18].

\section{Results}

\subsection{Hepatoprotective Evaluations}

\subsubsection{Malondialdehyde (MDA) and Catalase (CAT)}

The activity of MDA in untreated mice (negative control) was $(5.93 \pm 0.25)$ Unit/L, while the activity of catalase was $(0.35 \pm 0.02)$ Unit/L. After mice treated with cyperus rotundus methanolic extract the activity of MDA was $(3.65 \pm 0.96)$ Unit/L, the activity of catalase was $(0.74 \pm 0.03)$ Unit/L. After Glucophage treatment the activity of MDA was $(8.67 \pm 0.18)$ Unit/L, while the activity of catalase was $(0.23 \pm 0.01) \mathrm{Unit} / \mathrm{L}$. Finally, after treatment with interaction between Cyperus rotundus methanolic extract and Glucophage the activity of MDA was (8.20 \pm 0.94$) \mathrm{Unit} / \mathrm{L}$, while the activity of catalase was $(0.63 \pm 0.03)$ Unit/L (Table 1$)$.

Table 1. Effects of Cyperus rotundus methanolic extract and Glucophage on MDA and Catalase activity in liver tissue homogenate.

\begin{tabular}{llll}
\hline Group & Dose & MDA (mean \pm S.E) (Unit/L) & Catalase(mean \pm S.E) after 10 minutes (Unit/L) \\
\hline NegativeControl & & $5.93 \pm 0.25^{\mathrm{B}}$ & $0.35 \pm 0.02^{\mathrm{C}}$ \\
Plant extract & 200 & $3.65 \pm 0.96^{\mathrm{C}}$ & $0.74 \pm 0.03^{\mathrm{A}}$ \\
Drug & 500 & $8.67 \pm 0.18^{\mathrm{A}}$ & $0.23 \pm 0.01^{\mathrm{D}}$ \\
Plant+Drug & $200+500$ & $8.20 \pm 0.94^{\mathrm{A}}$ & $0.63 \pm 0.03^{\mathrm{B}}$ \\
\hline
\end{tabular}

Different letters: Significant difference $(\mathrm{P} \leq 0.05)$ between means.

\subsubsection{Aspartate Aminotransferase (AST), Alanine Aminotransferase (ALT) and Alkaline Phosphatase (ALP)}

The level of AST in untreated mice (negative control) was $(16.66 \pm 1.45) \mathrm{Unit} / \mathrm{L}$, while the activity of ALT was $(28.33 \pm 2.60)$ Unit/L, and the activity of ALP was $(35.00 \pm 2.88$ Unit/L). After, cyperus rotundus methanolic treated groups, the activity of AST was $(20.00 \pm 1.15) \mathrm{Unit} / \mathrm{L}$, the activity of ALT was $(22.00 \pm 3.78)$ Unit/L, and the activity of ALP was $(38.66 \pm 3.52)$ Unit/L. After Glucophage treatment the activity of AST was $(44.00 \pm 2.30) \mathrm{Unit} / \mathrm{L}$, while the activity of ALT was $(56.33 \pm 4.25)$ Unit/L, and the activity of ALP was $(80.00 \pm 2.88)$ Unit/L. Finally, after treatment with interaction between Cyperus rotundus methanolic extract and Glucophage the activity of AST was $(32.66 \pm 2.60) \mathrm{Unit} / \mathrm{L}$, while the activity of ALT was $(38.00 \pm 1.154) \mathrm{Unit} / \mathrm{L}$, and the activity of ALP was (43.66 \pm 0.88$)$ Unit/L (Table 2).

Table 2. Effects of Cyperus rotundus methanolic extract and Glucophage on aspartate aminotransferase; AST and alanine aminotransferase; ALT and alkaline phosphatase; ALP) in sera.

\begin{tabular}{llll}
\hline Group & Dose (mg/kg) & AST (mean \pm S.E) (Unit/L) & ALT (mean \pm S.E) (Unit/L) \\
\hline Negative Control & & $16.66 \pm 1.45^{\mathrm{C}}$ & $28.33 \pm 2.60^{\mathrm{BC}}$ \\
Plant extract & 200 & $20.00 \pm 1.15^{\mathrm{C}}$ & $22.00 \pm 3.78^{\mathrm{C}}$ \\
Drug & 500 & $44.00 \pm 2.30^{\mathrm{A}}$ & $35.00 \pm 2.88^{\mathrm{C}}$ \\
Plant+Drug & $200+500$ & $32.66 \pm 2.60^{\mathrm{B}}$ & $56.33 \pm 4.25^{\mathrm{A}}$ \\
\hline
\end{tabular}

Different letters: Significant difference $(\mathrm{P} \leq 0.05)$ between means 


\subsection{Histopathological Appraisal of Liver}

\subsubsection{Negative Control}

Normal liver which consist of central vein, surrounded by hepatocyte cells.

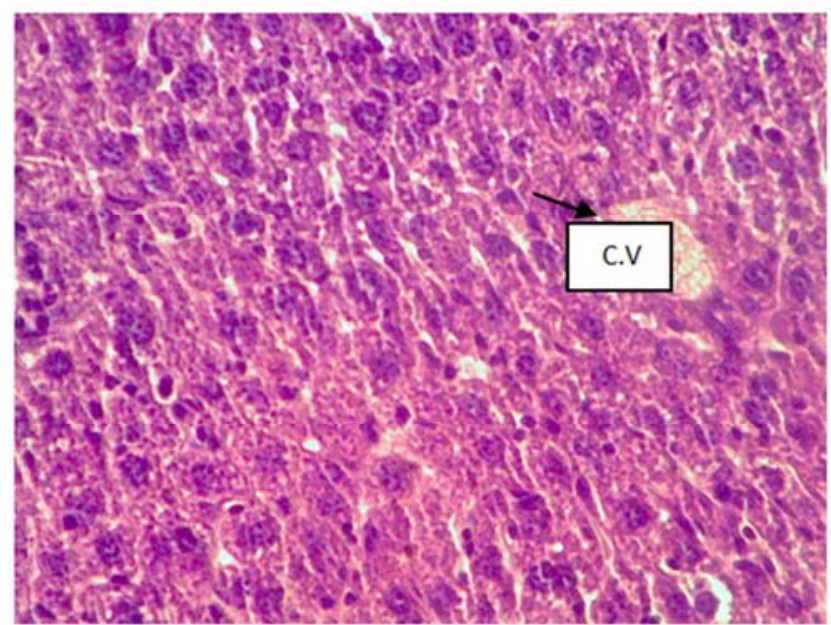

Figure 1. Micrograph of liver from negative control group showed normal liver area section (H\& E, 40X).

\subsubsection{After Treated with Cyperus Rotundus}

No histological alterations were observed in the liver of Cyperus rotundus treated group, except Mild vascular Congestion in the liver few scattered degenerated. other section showed aggregation of monocelluler hepatocyte (figure2) in the portal area around bile duct.

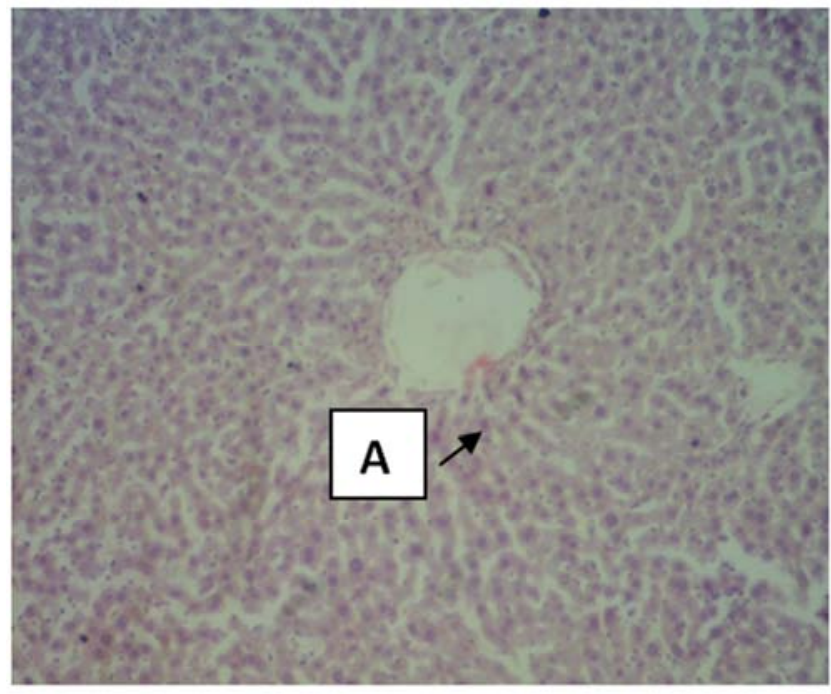

Figure 2. Histopathological section in the liver of mouse treated with Cyperus rotundus showed few scattered degenerated cells(A) (H\&E stain $10 X)$

Another section

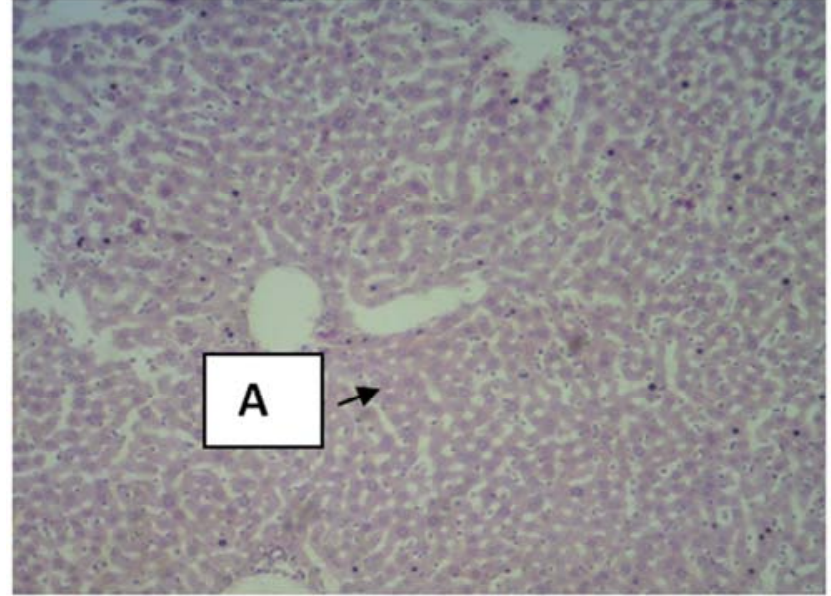

Figure 3. Histopathological section in the liver of mouse treated with Cyperus rotundus showed showed few scattered degenerated cells(A) (H\&E stain 40X).

\subsubsection{After Treated with Glucophage}

Liver showed hepatic lobule with mild dilated sinusoids and few inaddition in other section showed normal hepatic lobular architecture with few hepatocytes having pyknotic nuclei (Figure 4).

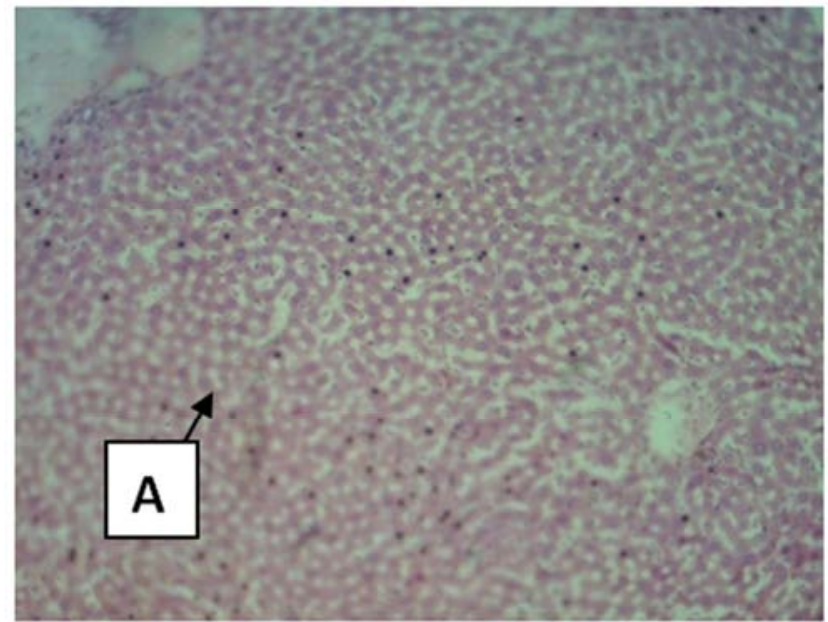

Figure 4. Histopathological section in the liver of mouse treated with Glucophage showed hepatic lobular architecture with few hepatocytes having pyknotic nuclei(A) (H\&E stain10X).

\subsubsection{After Treated with Cyperus Rotundus and Glucophage}

The main lesions in the examined liver of this group characterized by mononuclear cells aggregation mainly lymphocytes around central veins, blood vessels and bile ducts in the liver. 


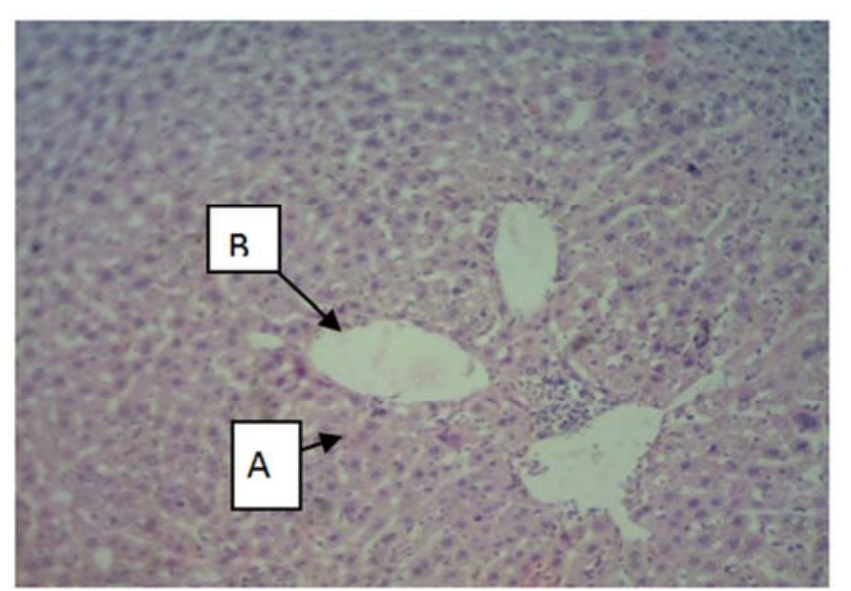

Figure 5. Histopathological section in the liver of mouse treated with Cyperus rotundus and Glucophage showed multiple aggregation mononuclear cells $(A)$ around central vein $(B)(H \& E$ stain 10X).

\section{Discussion}

Liver is the foremost site of detoxification and the primary target of drug exposure in the body. elevated levels of drugs cause various hepatic disorders by producing prooxidants/reactive oxygen species (ROS), which are proficient to induce cellular damage in a variety of ways by affecting the cellular biomolecules, such as lipids, DNA and proteins [19] catalase activity while increased (MDA) and also increased (AST, ALT and ALP) [20].

The present study also revealed that $C$. rotundus methanol extract at the given dose had no harmful effect on liver function in helthy mice. This indicated that the plant protects against free radicals and inhibits inflammatory mediator synthesis and release [21]. This defensive effect has been attributed in part to flavonoids, although a possible synergistic or antagonistic effect of flavonoids with other compounds in the extracts cannot be disqualified. Flavonoids possess potent hepatoprotective activities and were conjectured as the main active contents [22]. It has been shown that protective agents exert their action against glucophageinduced liver injury, either through decreased production of free radical derivatives or due to the antioxidant activity of the protective agent itself [23]. Thus, the administration of C.rotundus significantly modulates the activities of AST, ALT and ALP. Therefore, it is suggested that in vivo, C.rotundus may scavenge free radicals and protect mitochondrial, endoplasmatic reticulum, and plasma membranes from damage induced by free radicals [24]. All of these findings explained the mechanism by which phenolic compounds especially flavonoid prevent hepatotoxicity due to their antioxidant properties [25]. Further studies demonstrated that $C$. rotundus contain essential oils, which significantly modulated the oxidative stress/anti-oxidant parameters (i.e. CAT, MDA, AST, ALT and ALP). The essential oils significantly restored the hepatic MDA level, showing the oil could scavenge the reactive free radicals that eventually reduced the oxidative damage to the tissues and subsequently improved the level of this anti-oxidant [26].
Histopathological examination of liver confirmed the result of tissue homogenate and serum markers. Previous studies have been showed that Cyperus rotundus and its ingredient compounds inhibit the free radical generation and act as antioxidant and free radical scavengers and it has also been demonstrated that treatment with $C$. rotundus inhibits the generation of superoxide radicals [27]. Glucophage acts by binding free iron in the blood stream and enhancing its elimination in the urine [28]. By removing excess iron, the agent reduces the damage done to various organs and tissues, such as the liver [29]. Normal-appearing hepatic lobular architecture, which suggest that treatment with either metformin or mifegymiso(DFX) reversed the hepatotoxic side effects of streptozotocin (STZ) diabetes[30]. The histopathological examination of liver section treated with $C$. rotund $u$ and Glucophage revealed that $C$. rotundus induces immunity and decreased the toxic effects of the drug through reduces free radical [31]. The observed protective effect of C. rotundus against the toxic effect of Glucophage and this may be attributed to the presence of flavonoids and terpenoids, which are the important plant constituents [32]. As discussed earlier, Flavonoids are a group of polyphenolic compounds with known properties that include free radical scavenging, inhibition of hydrolytic and oxidative enzymes and anti-inflammatory action leading to hepato protection [33].

\section{Conclusion}

Hepatoprotective effects of the extract were overwhelmed by their potentials in reducing the hepatic damage induced by glucophage drug. The results concluded that the Cyperus rotundus plant has strong antioxidant activity and hepatoprotective capacity by reducing the level of liver enzymes to normal value and the architecture of liver to normal state after damage by drug.

\section{References}

[1] Williamson G, Manach C, ClinNutr A J. Bioavailability and bioefficacy of polyphenols in humans. 81: 243-455. (2005).

[2] Edeogo HO, Okwn DF, Mbaebie BO. Phytochemical constituents of some Nigerian medicinal plants. Afri. J. Biotechnol.; 4(7): 685-688. (2005).

[3] Ghosh M, Singh, SP. A review on phytoremediation of heavy metals and utilization of its byproducts. Appl. Ecol. Environ. Res. 3(1): 1-18. (2005).

[4] Kilani S, Abdelwahed A, Chraief I, Ben AR, Hayder N, Hammami M, Ghedira K, Chekir-Ghedira L. Chemical composition antibacterial and antimutagenic activities of essential oil from (Tunisia) Cyperus rotundus. J. Essent. Oil Res. 17: 695-700. (2005).

[5] Puratchikody A, Devi NC, Nagalakshmi G. Wound healing activity of cyperus rotundus linn. Ind. J. of pharma. sciences. 68:97-101. (2006). 
[6] Dang GK, Parekar RR, Kamat SK, Scindia AM, Rege NN, Antiinflammatory activity of Phyllanthus emblica, Plumbago zeylanica and Cyperus rotundus in acute models of inflammation. Phytother Res. 25(6):904-8. (2011).

[7] Nagulendran KR, Mahesh R, Begum V H. Preventive role of Cyperus rotundus rhizomes extract on age associated changes in glucose and lipids Pharmacology on line. 2: 318-325. (2007).

[8] Kumar SVS, Mishra H. Hepatoprotective Activity Of Rhizomes of Cyperus rotundus Linn Against Carbon Tetrachloride-Induced Hepatotoxicity.67(1): 84-88. (2005).

[9] Thanabhorn S, Jaijoy K, Thamaree S, Ingkaninan K, Panthon A. acute and Subacute Toxicities of the Ethanol Extract from the Rhizomes of Cyperus rotundus Linn., J. of Pharma. Sciences. 32(1-2): 15-22. (2005).

[10] Evans JM, Ogston SA, Emslie-Smith A, Morris AD. Risk of mortality and adverse cardiovascular outcomes in type 2 diabetes: a comparison of patients treated with sulfonylureas and metformin. Diabetologia. 2006;49:930-936.

[11] Hotamisligil GS. Inflammation and metabolic disorders. Nature.;444:860-867.( 2006).

[12] Fua W, Chena J, Caia Y, Leia Y, Chenb L, Peic L, Zhoua D, Lianga X, Ruana J. Antioxidant, free radical scavenging, antiinflammatory and hepatoprotective potential of the extract from Parathelypteris nipponica (Franch. et Sav.) Ching. J. Ethnopharmacol.; 130: 521-528. (2010).

[13] Kumar A, Garg R, Prakash AK. Effect of St. John's Wort (Hypericum perforatum) treatment on restraint stress-induced behavioral and biochemical alteration in mice. $B M C$ Complement Altern Med. 7:18.(2010).

[14] Guidet B, Shah SV. Enhanced invivo $\mathrm{H}_{2} \mathrm{O}_{2}$ generation by rat kidney in glycerol - induced renal failure. AJP. Renal Physiolol. 257: 440-445. (1989).

[15] Huo H Z, Wang B, Liang YK, Bao YY, Gu Y. Hepatoprotective and Antioxidant Effects of Licorice Extract against $\mathrm{CCl}_{4}$-Induced Oxidative Damage in Rats. Int $\mathrm{J}$ Mol Sci.12 (10): 6529-6543. (2011)

[16] Reitman S, Frankel S. A colorimetric method for the determination of serum glutamic oxalacetic and glutamic pyruvic transaminases Am. J. Clin.pathol.; 28 (1):5663.( 1957)

[17] Rowe A, Zhang L, Hussain A, Braet F, Ramzan I. Assessment and histological analysis of the IPRL technique for sequential in situ liver biopsy. Comp Hepatol.; 10: 73.(2011).

[18] Perez-Serrano, J., Denegri, G., Casado, N. and FodriguezCabaeiro, F. (1997). In vivo effect of oral albendazole and albendazole sulphoxide on development of secondary echinococcosij in mice. Int J Parasitol., 27: 1341-1345.

[19] Meena AK, Yadav AK, Niranjan US, Singh B, Nagariya AK. Verma M., Review on Cyperus rotundus - A potential herb. Int. J. Pharmaceut Clin Res.; 2(1): 20-22.(2010).

[20] Cone CJ, Bachyrycz AM Murata GH. Hepatotoxicity associated with metformin therapy in treatment of type 2 diabetes mellitus with nonalcoholic fatty liver disease. Ann. Pharmacother.;44:1655-1659.( 2010).

[21] Mandal S, Hazra B, Sarkar R, Biswas S, Mandal N. Assessment of the anti oxidantand reactive oxygen species scavenging activity of methanolic extract of caesalphina crista leaf. Evid Based complement alternat Med. 1-11. (2009).

[22] Shamkuwar PB, Hoshamani AH, Gonjari ID. Antipasmodic effect ofCyperus rotundus L. (Cyperaceae) indiarrhea. Scholars Res. Library.; 4: 522-524. (2012).

[23] Rajkumar V, Guha G, Kumar RA, Mathew L. Evaluation of anti oxidant activities of C.rotundus Rhizome. Rec. Nat. Prod.; 4: 38-48. (2010).

[24] Yazdanparast R, Ardestani A. In vitro antioxidant and free radical scavenging activity of Cyperus rotundus. J. Med. Food.; 10: 667-674. (2007).

[25] Chaulya NC, Haldar PK, Mukherjee A. Anti diarrhoeal activity of methanolic extract of the rhizome of Cyperus tegetum Roxb., Int. J. Pharm Pharmaceuti Sci.;3(1):133-135. (2011).

[26] Pal D, Dutta S, Sarkar A, evaluation of CNS activities of ethanol extract of roots and rhizomes of Cyperus rotundus in mice, Acta Poloniae Pharmaceut Drug Res.; 66(5), 535-541. (2009).

[27] Oladipupo AL, Oyedeji AO. Chemical composition of the essential oils of Cyperus rotundus L. from South Africa. Molecules.;14:2909-2917. (2009).

[28] nChoi EY, Kim EC, Oh HM, Kim S, Lee HJ Cho EY, et al. Iron chelator triggers inflammatory signals in human intestinal epithelial cells: Involvement of p38 and extracellular signalregulated kinase signaling pat hways. J. of Immuno.; 172(11):7069-77. (2004).

[29] Trelle S, Reichenbach S, Wandel S, Hildebr P, Tschannen B, Villiger PM, et al. Cardiovascular safety of non-steroidal antiinflammatory drugs: network meta-analysis. BMJ.;342:c7086. (2011).

[30] Kilani S, Ledauphin J, Bouhlel I, Ben SM, Boubaker J, Skandrani I, etal. Comparative study of Cyperus rotundus essential oil by a modified GC/MS analysis method. Evaluation of its antioxidant, cytotoxic, and apoptotic effects. Chem. Biodivers.;5: 729-742.( 2008).

[31] Dang GK, Parekar RR, Kamat SK, Scindia AM, Rege NN. Antiinflammatory activity of Phyllanthus emblica, Plumbago zeylanica and Cyperus rotundus in acute models of inflammation., Phytother Res. 2011 Jun;25(6):904-8. doi: 10.1002/ptr.3345. Epub Dec 3. (2010).

[32] Hemanth K K, Razack S, Nallamuthu I. Khanum F. Phytochemical analysis and biological properties of Cyperus rotundus L. Ind. Crop Prod.; 52: 815-826.( 2014).

[33] Cone CJ, Bachyrycz AM, Murata GH. Hepatotoxicity associated with metformin therapy in treatment of type 2 diabetes mellitus with nonalcoholic fatty liver disease. Ann Pharmacother,; 44:1655-1659. (2010). 